\title{
DETERMINANTS OF GROWTH AND INTERNATIONAL COMPETITIVENESS OF SMALL ENTERPRISES
}

\author{
MAGDALENA BROJAKOWSKA-TRZĄSKA \\ University of Szczecin, Faculty of Management and Economics of Services, POLAND \\ e-mail: magdalena.brojakowska@wzieu.pl
}

\begin{abstract}
\begin{tabular}{l|l} 
RECEIVED & 6 November 2018
\end{tabular}
ACCEPTED 3 December 2018

JEL

CLASSIFICATION

$F 18, F 23, F 29$

KEYWORDS international competitiveness, determinants of the rise, internationalization, small enterprises

ABSTRACT Small enterprises of today operate in conditions of constant changes and amendments to the requirements brought about by the market. Unstable conditions of functioning of small enterprises force them to conduct business activities in such a way that takes into account all the determinants of their optimal functioning, as well as allows continuous growth, development and a boost to competitiveness. The presented deliberations constitute a review of the most important factors determining the existence and functioning of small enterprises that will result in a growth of the enterprise in the long-term, as well as an increase in its competitiveness.
\end{abstract}

\section{Introduction}

Enterprises operating on the market, in particular those active on the global scene, cannot exist, let alone survive and develop, without taking into account the requirements of the market. Undoubtedly, the basic challenge faced especially by a small enterprise is to achieve such structure, operating instruments and results that will contribute to the acquisition of a significant competitive position against other entities in a given industry environment. 
The following deliberations concern the analysis of basic conditions, the fulfilment of which represents the level of international competitiveness of a small enterprise and its individual growth.

\section{Determinants of growth of small enterprises}

The growth category of a small enterprise is perceived primarily in terms of assessing any quantitative changes concerning various metrics, such as employment, income, capital, etc. The concept of growth is often equated with the development of an enterprise, and although it reflects changes of a qualitative nature, both the concept of "growth" and "development" of the enterprise are related to the possibilities of its existence, survival, exploiting opportunities and achieving successes.

In order to perform an analysis of factors that significantly affect the growth of small enterprises, the research should start with a personal factor, which is primarily the entrepreneur themselves. The company's growth is perceived as a measure of the entrepreneur's success.

Furthermore, entrepreneurial characters, that is, genuine, active entrepreneurs who strive to develop the enterprise; and people with a low level of entrepreneurship, i.e. passive, conservative entrepreneurs, who are concentrated not on growth, but survival, should be distinguished among the group of owners - entrepreneurs.

Numerous research (Bławat, 2004, p. 26) presents the general trend, which shows that younger owners want to develop more eagerly, are willing to devote more time for the company, but also have lower level of creditworthiness and experience. On the other hand, older owners have greater chances for taking out loans, employ their experience, but are more cautious and less willing to take risks, as well as have different motivations and goals. Therefore, it is assumed that middle-aged entrepreneurs have the greatest opportunities.

Moreover, small enterprises have greater possibilities to grow when (Bławat, 2004, p. 26):

- companies are founded by more than one person,

- the owners are mainly people who completed at least secondary education (people with a higher level of education are more likely to develop their companies),

- the profession performed before staring one's business has developed a habit to constantly improve (this applies mainly to individuals who have previously occupied managerial positions and have more experience and imagination),

- the entrepreneur is characterized by high managerial experience (managerial experience is generally identified with the number of years of work in the industry, the managerial position, the number of established companies, etc.).

In theory, the following characteristics-needs of an entrepreneur can be distinguished: autonomy, achievements, domination, proactivity, innovation, self-control, diligence, endurance, and moderate risk-taking tendency.

The character traits of a given entrepreneur, through the structure of their motivation, may also have an impact on their attitude towards the growth of the enterprise seen as a priority objective. It is therefore obvious that the lack of motivation is the basic barrier to the growth of a small enterprise. In a small enterprise, the influence of the determinant of development is the managing person is more complex than in a large enterprise. SMEs can be managed by their owners or by employees for this purpose, managers who can additionally have a small one share in ownership or not have it at all. They differ in motivation, because for the employees managing the company is only a place of work. In turn, for the owner it is often a source of autonomy and a guarantor maintaining a given lifestyle. Differences in management are a consequence their competence and ownership structure. One-man property 
gives control over the entire enterprise, the owner can make strategic decisions decisions without agreement with shareholders. Therefore, enterprises managed by the owners are able to react faster and more effectively on market signals (Steinerowska-Streb, 2012, pp. 748-749).

When analysing the growth of a small enterprise from the perspective of factors related to the company, an inverse correlation between its growth, age and size can be observed. This means that the longer an enterprise operates on the market, the smaller and less effective its development may be. In spite of how paradoxical this statement may sound, it does reflect a situation when, after the phase (stage) of maturity, a small enterprise may enter the stage of decline (limitation of activity), in which case its size will not contribute to its development or growth, e.g. competitiveness. The above-described situation will not take place until the small enterprise enters the stage of maturity, in which case, the increase in its size will probably reflect its development.

The organizational and legal form of the enterprise should also be recognized. Due to the possibility of enjoying the limited liability and, consequently, increasing the trust of banks when granting financial resources, the most recommended organizational and legal form for small (also medium) enterprises is limited liability company, although the choice of this form does not guarantee success.

When discussing the determinants that affect the operation of a small enterprise concerned, it is also worth mentioning localization of an enterprise.

Although a company's growth depends on its location, this dependence is primarily linked to the sector of the small enterprise. It is not true that a peripheral location leads an enterprise, especially micro and small, to a business failure. If a small enterprise has access to factors of production, is innovative and highly qualified, then it is highly probable to achieve success, development and growth despite being peripherally located. This is particularly noticeable in the case of manufacturing companies. On the other hand, service or even trading enterprises should pay particular attention to the size of the market and the demand when choosing their locations.

Literature research confirms the positive impact of research and development $(R \& D)$ for enterprise growth. However, they also appear here doubts. Research and development can limit the growth of companies because combining the risks associated with research, development and operations SMEs can lead to financing problems. Required access to significant financial resources (internal or external), in the case of small and medium-sized enterprises can prove to be problematic (Serrasqueiro, Nunes, Leitao, Armada, 2010, p. 1075).

A factor strongly associated with the growth possibilities of small enterprises is the accessibility of this sector to the sources of financing. The indicated availability depends not only on the size of the enterprise, but also on its current stage of development.

As the small enterprise enters the next stages of growth, the number of possibilities to choose its sources of financing also increase.

The following general trends can be observed (Third Round..., 2002, p. 7):

a) the basic source of funding is own capital, starting from the creation of a small enterprise to the stage of its early growth; in subsequent stages, the source is the obtained profits;

b) public funds, if available, can finance a small enterprise regardless of the stage of its development;

c) regional development agencies support enterprises only in the stage of creation and early growth;

d) banks can generally finance the development of an enterprise at every stage;

e) informal investors (business angels) most often finance the enterprise in the stages of start-up, early growth and expansion; 
f) venture capital funds can be used from the start-up stage of the enterprise to its maturity stage;

g) financing through the public capital market and institutional investors becomes a source of financing for a small enterprise only at the stage of expansion, in which the enterprise is likely to transform into a medium-sized, mature enterprise.

Table 1 presents the availability of modern sources of financing for a small enterprise in its different stages of development.

Table 1. Availability of specific forms of financing for a small enterprise depending on the stage of development

\begin{tabular}{lccccc}
\hline \multirow{2}{*}{ Development stage } & \multicolumn{4}{c}{ Source of financing } \\
\cline { 2 - 6 } & credit & leasing & factoring & venture capital & issue of shares \\
\hline Venture concept & unavailable & unavailable & unavailable & difficult to access & unavailable \\
Start-up & difficult to access & moderately available & unavailable & difficult to access & unavailable \\
Small company & moderately available & easy to access & moderately available & moderately available & unavailable \\
Medium-sized company & easy to access & easy to access & easy to access & difficult to access & difficult to access \\
\hline
\end{tabular}

Source: own work based on Ostaszewski (2003), p. 331, Bławat (2004), p. 26.

The low level of availability of foreign sources of financing, including special forms, in the initial phases of the life cycle of a small enterprise results mainly from the high-risk venture. Foreign capital comes mainly from investors, who have sufficient knowledge about a given project, its chances, threats, as well as accept the occurrence of risk at a higher level than in the case of an enterprise that is, for example, at the stage of maturity. The capital offer can be extended when the capacity of a small enterprise to generate profits is revealed. It is then that specific forms of external financing, such as leasing or factoring, become especially important.

\section{International competitiveness of small enterprises and its determinants}

When analysing the international competitiveness of a small enterprise, the national economy (international aspect) or the position of the small enterprise (aspect of an economic entity) may serve as a point of reference.

The concept of international competitiveness most often refers to the level of the entire national economy presented in comparison with the economies of other countries. Nevertheless, the definition of international competitiveness can be also understood in two ways (Plawgo, 2004, p. 13). The first definition refers to the place of a given country in the world economy and foreign trade business performance, where competitiveness is understood as the ability to maintain or even increase market share. As far as the other definition of international competitiveness is concerned, competitiveness regards the country's ability to produce goods and services, which, in the conditions of free and sound trade, are accepted on the international market, while maintaining and increasing real income of the population in the long run.

States that increase their citizens' real income as well as enterprises that make it possible for their owners to increase their value are considered competitors. Not only the economy as a whole, but also the enterprise, even a micro and small one, which is able to generate more wealth than competitors on global markets, shows international competitiveness.

International competitiveness is undoubtedly a feature of microeconomic entities, i.e. mainly enterprises. However, since international competitiveness is also used to describe the economy as a whole, the mutual relations 
between the competitiveness of individual small enterprises and the national economy should also be taken into consideration.

Therefore, it can be concluded that the competitiveness of the national economy is based on the competitiveness of enterprises, especially small enterprises.

When analysing the international ability of the small enterprise sector to compete, factors that vary at different levels of the economy should be taken into account. The factors shaping international competitive ability and their interdependence have been comprehensively presented in the so-called systemic competitiveness concept. According to the concept, there are strong relationships between the four levels of competitiveness determinants of small enterprises. The indicated levels are: meta, macro, meso and micro level. ${ }^{1}$

The most important factors affecting the international competitiveness of a small enterprise at the meta level, are:

a) agreement within society about the principles of market economy and openness to the world;

b) the basic structure of the legal, political, economic and social systems that is at the level allowing the concentration of market participants' activities, enabling social communication, learning process, strengthening national innovation, competitive, development and growth advantages;

c) will and ability to implement development strategies (especially medium and long-term) focused on technology and competitiveness, with a high degree of organization, cooperation and strategy on the part of national groups of market participants.

The macro level creates a framework for effective competition and takes into account the following determinants of the competitiveness of a small enterprise:

- stable macroeconomic environment,

- competition policy to prevent monopolies,

- exchange and trade policy that does not hinder export.

The macro level includes budgetary, monetary, fiscal, competition, monetary and commercial policies.

With regard to the meso level, it can be noted that it first and foremost concerns shaping the environment in which a small enterprise operates. Of particular importance are:

- infrastructure policy that creates a material, transport and telecommunications base,

- sector, education-training, research policies,

- regional, import and export policies.

At the micro level, the most important are the determinants of:

- effective management of the technical and organizational process of learning at the level of a small enterprise,

- cooperation between small enterprises and their suppliers, service companies, research institutions,

- optimal division of labour between enterprises.

When applying the system approach to competitiveness, it can be seen that most competitive countries are those that not only promote competition between enterprises, but also actively shape their location and competitive

${ }^{1}$ Concept of systemic competitiveness and individual levels of factors are discussed on the basis of Meyer-Stamer, 1996, pp. 1-5. 
advantages (Plawgo, 2004, p. 23). The mechanism that allows building an advantage is, above all, active learning within organized groups of entities.

When analysing the determinants shaping the international competitiveness of small enterprises, internal and external origin should also be taken into account.

Internal factors of international competitiveness regarding small enterprises are related to their ability to develop their own competitive advantages. Apart from finding a niche market, the most important factor affecting the possibility of achieving a competitive advantage by a small enterprise is access to resources as well as their effective use. Resources that can form the basis of a sustainable competitive advantage of a small enterprise should be strategically important (the base of a successful strategy); be rarely possessed by current and future competitors; be difficult to reproduce and substitute for other types of resources by competitors.

In addition to resources, a remarkable determinant of the competitiveness of a small enterprise is the level of its competence. It is widely recognized that every enterprise should focus on things it does best. Therefore, a small enterprise should focus on its "core" skills that distinguish them from competitors, and thus ensure long-term development and growth. The individual competences and skills of a small enterprise should be constantly developed and used during various company's activity by creating, for example, interdisciplinary teams.

An effective increase of competitiveness shown by small enterprises, especially international competitiveness and foreign expansion, takes place based not only on internal competitive advantage. An important role is played by external determinants of the competitive advantage of a small business entity.

An enterprise creates and maintains its competitive advantage not in the economy as a whole, but in the segment or sector in which it operates. International competitive advantage of a small enterprise in terms of external determinants is created based on four basic groups of factors: ${ }^{2}$

1. Factors of production - position occupied by a given country in terms of such factors as: qualified labour force, sector infrastructure.

2. Demand conditions - the nature of domestic demand for products in a given sector.

3. Related and supportive sectors - presence or absence of supply and other related sectors in a given country that are competitive on an international scale.

4. Strategy, structure and competition of companies - conditions in a given country that determine the way of creating small enterprises and managing them, as well as the nature of national competition.

Small enterprises are more dependent on their closer local regional environment than bigger enterprises. Therefore, the groups of factors indicated above should refer to a greater extent not to the State level, but to the region or the local environment.

In this respect, it can be concluded that the factor that may adversely affect the competitive position of a small enterprise may be a low level of entrepreneurship, striving for success, development and growth, especially in the long run, as well as the fact that in the case of competition between local competitors, non-market instruments can be used to a greater extent than it the case of big enterprises.

2 The indicated groups of factors were presented by M.E. Porter, who coined the concept of competitive advantage of nations (the so-called Porter's forces). 


\section{Conclusions}

The rise of small businesses in the economy at the turn of the century was influenced by the simultaneous appearance of several phenomena. The dissemination of new information and telecommunications technologies played a crucial role, which made access to information easy, transaction costs decreased, geographic approximation of markets took place, promotion expenditures were reduced and access to banking services was cheaper. Thanks to these technologies, a small entrepreneur easily overcomes cost barriers. Information technology also creates great opportunities to provide work at home and in a mobile mode. Modern IT technologies expand niches in which small companies can emerge and develop. Another phenomenon that favors the creation of small businesses is the outsourcing and offshoring of services. Small business is also attractive in traditional industries, which satisfy the demand for non-standard goods and services, with an individual feature, tailored to the individual needs of customers in growing health (Lichniak, 2011, p. 2).

The international competitive position of a country should be understood as a resultant of competitive positions of all economic entities operating within its economy. Moreover, it should be noted that the ability to compete, analysed based on the results, applies independently to individual enterprises, including micro and small enterprises, as well as the entire economy. International competitiveness of a small enterprise is conditioned not only upon microeconomic factors, but also determinants at the macro and meso level.

The analysis of internal conditions of the competitiveness of a small enterprise indicates that the limited resources and competences result in the fact that apart from microeconomic factors of competitiveness and growth, where the opportunity to develop a small enterprise is significantly influenced by the entrepreneur himself; as well as the location of the small enterprise and access to external sources of financing; of special importance become the connections of the small enterprise with the environment that supports its opportunities for international competition and growth.

\section{References}

Bławat, F. (ed.) (2004). Przetrwanie i rozwój małych i średnich przedsiębiorstw. Gdańsk: Scientific Publishing Group. Lichniak, I. (ed.) (2011). Determinanty rozwoju przedsiębiorczości w Polsce. Warszawa: Oficyna Wydawnicza SGH.

Meyer-Stamer, J. (1996). Konkurencyjność systemowa. Gospodarka Narodowa, 3, 1-5.

Ostaszewski, J. (ed.) (2003). Prawno-ekonomiczne aspekty rozwoju przedsiębiorczości, cz. 2. Pobudzanie małej i średniej przedsiębiorczości. Warszawa: Agencja Marketingu i Reklamy Heil.

Plawgo, B. (2004). Zachowania małych i średnich przedsiębiorstw w procesie internacjonalizacji. Warszawa: Instytut Organizacji i Zarządzania w Przemyśle "Orgmasz".

Serrasqueiro, Z., Nunes, P., Leitao, J., Armada, M. (2010). Are there nonlinearities between SME growth and its determinants? A quantile approach. Industrial and Corporate Change, 4, 1075.

Steinerowska-Streb, I. (2012). The determinants of enterprise profitability during reduced economic activity. Journal of Business Economics and Management, 13, 748-749.

Third Round Table of Bankers and Mes Final Report (2002). Centre for Strategy and Evaluation Services, August.

Cite this article aS: Brojakowska-Trzaska, M. (2018). Determinants of growth and international competitiveness of small enterprises. European Journal of Service Management, 4 (28/1), 23-29. DOI: 10.18276/ejsm.2018.28/1-03. 